\title{
Experimental Investigation on the Effects of Mixing Hot and Cold Water on the Concrete Properties in Ethiopia
}

\author{
Chimdi Gadafa Benti ${ }^{1 *}$, Kumar Shantveerayya ${ }^{2}$ \\ ${ }^{1}$ Lecturer and Associate Dean for School of Civil Engineering and Architecture at Adama Science and Technology University Ethiopia \\ ${ }^{2}$ Lecturer, Adama Science and Technology University Ethiopia
}

Article History
Received: 09.10 .2020
Accepted: 25.10 .2020
Published: 04.11 .2020
Journal homepage:
https://www.easpublisher.com/easjecs
Quick Response Code

Abstract: In Ethiopia, the weather condition is different at different places due to change in altitude, the usage of water temperature in casting the concrete place an important role. In the present research study it has an examined the effects of different mixing water temperature on the performance on fresh and harden concrete properties which are made with locally available cement. In this research testing is done for both plastic and hardened concrete with different temperatures of water at $15^{\circ} \mathrm{C}, 25^{\circ} \mathrm{C}$ and $40{ }^{\circ} \mathrm{C}$ with constant water - binder ratio 0.5. Based on our experimental results and observations, we concluded that decrease in compressive and flexural strength at $10^{\circ}$ and increase in strength for $40^{\circ}$ Similarly it was observed in workability also. Hence in practical there is no need of change in mix design / take additional precaution for change in temperature of water up to $40^{\circ} \mathrm{C}$. The higher temperature of mixing water in bleeding, segregation and other properties can be added for further relative study.

Keywords: Temperature, slump, workability, strength and setting time.

Copyright (C) 2020 The Author(s): This is an open-access article distributed under the terms of the Creative Commons Attribution 4.0 International License (CC BY-NC 4.0) which permits unrestricted use, distribution, and reproduction in any medium for non-commercial use provided the original author and source are credited.

\section{INTRODUCTION}

In construction industry particularly transportation projects, where rigid pavement is used for road construction and concrete is done in large surface area of slabs in commercial buildings, where concrete is exposed to different climatic conditions and where temperature changes from morning to evening. It is also observed that when there is a change in temperature will also change in water temperature accordingly. In construction industry concrete is manufactured under differing environmental conditions. There are many factors which are effecting the properties of concrete like quality of ingredient and workmanship, weather condition, water purity level and water temperature. In Ethiopia most of the construction and consultant engineers are not aware of how water temperature effects the concrete properties, which is one of the parameter that effects the concrete property. It is observed that local builder/contractor simply add water based on purity standard which is portable water.

In Ethiopia some region has different environmental conditions example Semera has higher temperature $40^{\circ} \mathrm{C}$ while Debre berhan has very lowest temperature $15^{\circ} \mathrm{C}[1]$. Discussed about the effect related to hot water curing temperature between $40^{\circ}-60^{\circ} \mathrm{c}$ on concrete properties which is made up using GGBS has yielded maximum compressive and tensile strength. Many researches have discussed about the early-stage concrete and stated that compressive concrete strength will decrease up to $50 \%$ with freezing temperature [2]. Also it was stated that if we maintain the concrete temperature from $10{ }^{\circ} \mathrm{C}$ for 48 hours, then concrete has resisting the capacity for the single freeze-thaw cycle. Different practical problems were discusses by [3] and given a technical solutions with related to the cold weather concreting, particularly related to early-stage of concrete hydration.

American concrete institute (ACI) guidelines mainly focused more on increasing the cement content with the substitution admixture for high early strength concrete by using type III Portland cement to accelerate the early setting time of concrete. Since water has high potential to store the heat which is generated during hydration time [3], by using the hot water in concrete mix will lead to rise the degree of heat in end production of concrete and setting time of concrete will be reduced due to the acceleration of hydration in concrete. Several earlier studies have also showed that the temperatures between $20-35{ }^{\circ} \mathrm{C}$ showed few disappointments in the final product [4]. According to the concrete society recommendations, mixing water 
temperature shall not to be more than $60-80{ }^{\circ} \mathrm{C}$ to avoid the problems of flash setting time of cement and to decrease the risk of blistering of concrete. The optimal mixing water temperature shall not be less than $60{ }^{\circ} \mathrm{C}$ for all concrete mix design was stated by [5].

However, an overall review showed just few research scholars / scientist have explored how the type of cement and their additives effect in concrete properties related to the compatibility on different mixing water and curing of temperature on concrete. Regarding to this subject and inconsistent literature conclusions from Ethiopia and other countries, which made skepticism among the researchers and practitioners in the field of practicing, the aim of this research is to address the influence of mixing water temperature ranges $15^{\circ} \mathrm{C}, 25^{\circ} \mathrm{C}$ and $40^{\circ} \mathrm{C}$ at 7, 21 and 28 days strength on concrete properties with constant water binder ratio 0.5 . The research focused setting time, workability, compressive strength, flexural strength.

\section{METHODOLOGY}

The experimental investigation has been carried out with a target compressive strength of 30 $\mathrm{MPa}$ by utilizing the materials which are locally available. The concrete mix design was done according to the ASTM. The temperature of water was maintained by keeping in fridge for $15^{\circ} \mathrm{C}$ as well heating up to $40^{\circ}$ $\mathrm{C}$ this water was used added during mixing time. 27 standard size cubes of size $150 \times 150 \times 150 \mathrm{~mm}$ and 9 beams of size $100 \times 100 \times 500 \mathrm{~mm}$ in length were casted to study the compressive strength and flexural strength of the concrete for 7, 21 and 28 days, slump test was during fresh state to study the workability of concrete at different temperature.

\section{Cement}

Locally available OPC cement was used in the casting of concrete.

\section{Coarse Aggregate (CA) and Fine Aggregate (FA)}

Concrete was prepared by using the locally available materials coarse aggregate and fine aggregate from Adama town. The gradation of CA and FA was done in accordance to ASTM C 136 and ASTM 33. Physical properties like apparent and bulk specific gravity and percentage of moisture absorption for coarse aggregates and fine aggregate has been evaluated as per ASTM C127 standards to avoid any inconsistency of concrete materials used as per ASTM C131. Summary of physical properties of CA and FA are shown in the table 1.

Table-1: Physical properties of aggregates

\begin{tabular}{|l|l|l|l|}
\hline Type of aggregates & $\begin{array}{l}\text { Apparent Specific } \\
\text { Gravity } \\
\left(\mathbf{g r a m} / \mathbf{c m}^{\mathbf{3}}\right)\end{array}$ & $\begin{array}{l}\text { Bulk Specific } \\
\text { gravity } \\
\left(\mathbf{g r a m} / \mathbf{c m}^{\mathbf{3}}\right)\end{array}$ & $\begin{array}{l}\text { \% of Water } \\
\text { Absorption }\end{array}$ \\
\hline Coarse aggregates & 2.70 & 2.72 & 4.4 \\
\hline Fine aggregates & 2.73 & 2.43 & 1.6 \\
\hline
\end{tabular}

To avoid any kind of inconsistency of materials used mix design was done in according to ASTM standards the specimens where casted and cured in controlled temperature at laboratory

\section{Mixing Water}

Locally available portable tap water is used for mixing water under temperatures between $15^{\circ} \mathrm{C}, 25^{\circ} \mathrm{C}$ and $40^{\circ} \mathrm{C}$, by keeping the water in fridge initially later ice is placed in water for lowering the temperature to maintain $15^{\circ} \mathrm{C}$ and heating the water using water heater up to $40^{\circ} \mathrm{C}$ as shown in figure 1 and 2 , in concrete mix design we didn't add any admixtures.

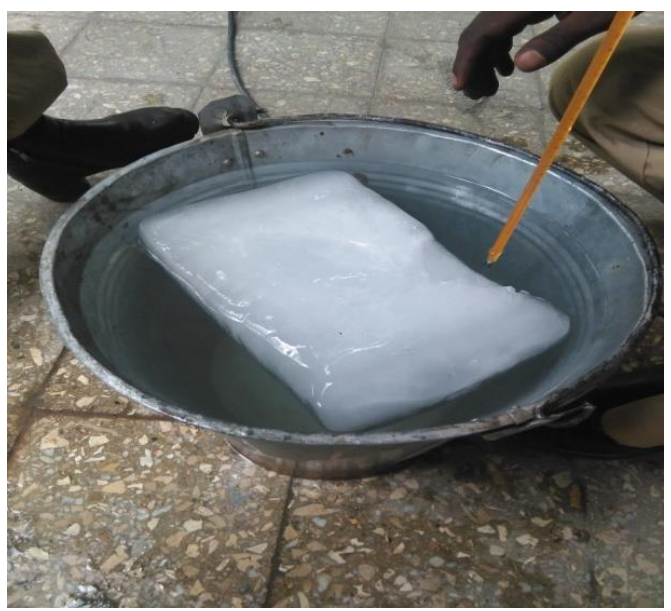

Fig-1: Cold water 


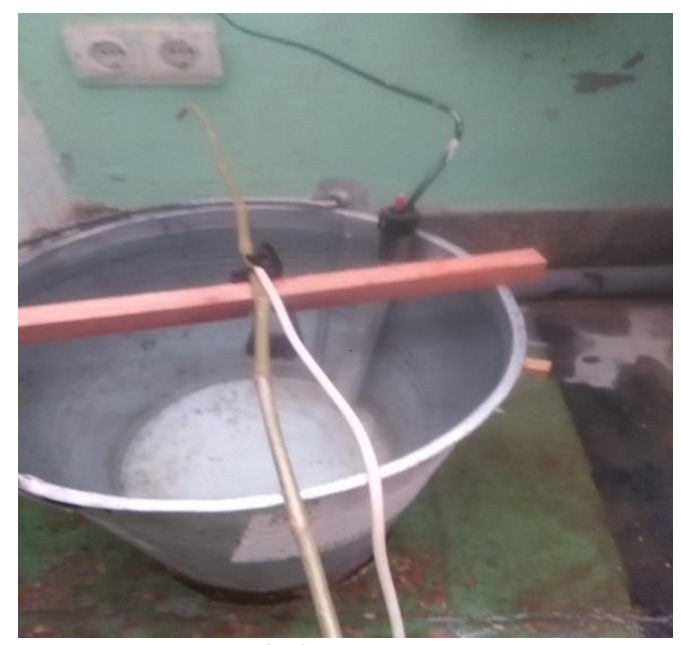

Fig-2: Hot water

\section{Concrete Mix Design and Production of Specimens}

Concrete mix design was done in accordance to the ASTM standards guidelines by considering 20 $\mathrm{mm}$ maximum nominal size aggregates with 80 to 100 $\mathrm{mm}$ as reference slump value. Water/ binder ratio
(W/B) and workability of fresh concrete are kept constraints in accordance to ASTM guidelines. Table 2 shows the quantity of materials used to achieve C30 grade concrete.

Table-2: Concrete mix design proportions for C30.

\begin{tabular}{|l|l|}
\hline Concrete components & Proportions in mass (kg) \\
\hline Cement & 387.4 \\
\hline Coarse aggregate & 1016.95 \\
\hline Fine aggregate & 665.85 \\
\hline Water & 193.7 \\
\hline $1 \mathrm{~m}^{3}$ concrete weight & 2300 \\
\hline
\end{tabular}

ASTM C 192, procedure was followed for mixing and casting the specimens, however little changes were done by considering the field. The entire specimen were casted separately at ambient laboratory temperature of $25^{\circ} \mathrm{C}$ with different mix temperature of water as per required. After casting of each specimen, the temperature of each specimens were measured to check whether is there any change in temperature level before and after casting specimens. All the specimens where cured at different ages of concrete 7, 21 and 28 days with controlled environmental conditions so as to avoid any kind of outdoor factors affecting the concrete properties. Harden concrete compressive strength property mainly depends on the curing condition of the specimens, hence standard procedure was followed in according to ASTM C31. All the specimens where kept at laboratory temperature for 24 hours for final setting of concrete in the mould. The specimens demolded and kept in curing tank for different age of testing. Before testing the specimens, all the specimens where removed and wiped with dry cloth and kept in the laboratory for one hour.

\section{Experimental and Analysis of Test Results Cement Paste Setting Time}

In this research study, the setting time of grey cement paste was done in accordance to ASTM C191 standards using Vicat apparatus. Table 3 shows the results of setting times of cement paste and these results are compared to the standard values of ASTM. The setting time mainly depends on the fines and chemical constitutes particularly to the gypsum and admixtures like fly-ash added during the production of cement. Water / binder ratio was done trial and error up to needle penetrated to $33-35 \mathrm{~mm}$ for initial setting time, which gives us an indicator for the concrete setting time [8].

Table-3: Initial setting time of cement paste using Vicat apparatus (ASTM C191)

\begin{tabular}{|c|c|c|c|c|}
\hline \multirow[t]{2}{*}{ Vicat apparatus setting time } & \multicolumn{3}{|c|}{ Experimental test results (Minuets) } & \multirow[t]{2}{*}{ *Limits } \\
\hline & $10^{0} \mathrm{C}$ & $25^{0} \mathrm{C}$ & $40^{0} \mathrm{C}$ & \\
\hline Initial setting time, Min. & 70 & 60 & 55 & $\geq 45$ \\
\hline Final setting time, Max. & 267 & 250 & 243 & $\leq 375$ \\
\hline
\end{tabular}

*ASTM C150 values for all the type of cement 


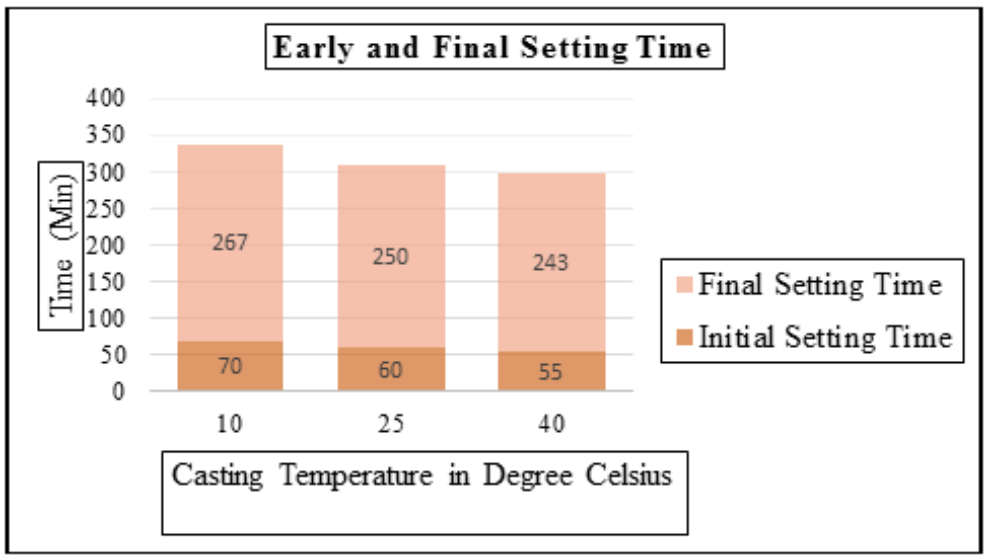

Fig-3: Temperature effect on initial and final setting of fresh concrete [9]

Temperature effect on workability of concrete (slump)

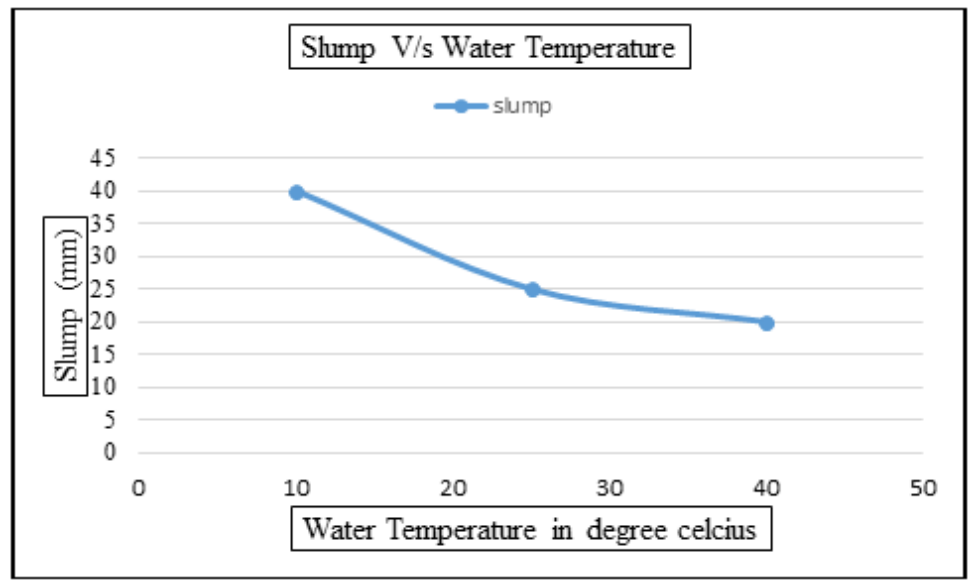

Fig-4: Effect of slump on mixing water temperature

From the test result it is observed that slump value ranges from $20-40 \mathrm{~mm}$ with different mixing water temperatures, however from figure 4 it is observed that increase in workability and slump with lower water temperature added at $10^{\circ} \mathrm{C}$. it is observed that there is loss of slump values reduces with the rise in water temperature, hence rise in the mix of temperature of water will causes the reduction of slump value which indicates the increase in workability of concrete. There will be a high thermal energy at high water temperature in concrete [6] due to exothermic reaction of hydration and water vaporization takes place from concrete which is observed at $40^{\circ} \mathrm{C}$ temperature of mix water and it was observed there is a slight rise in water demand for mix water temperature at $40^{\circ} \mathrm{C}$ which may lead to drying shrinkage in concrete. It was stated that additional amount of water is required [7] at higher temperature to reduce the drying thermal shrinkage.

\section{Concrete Compressive Strength}

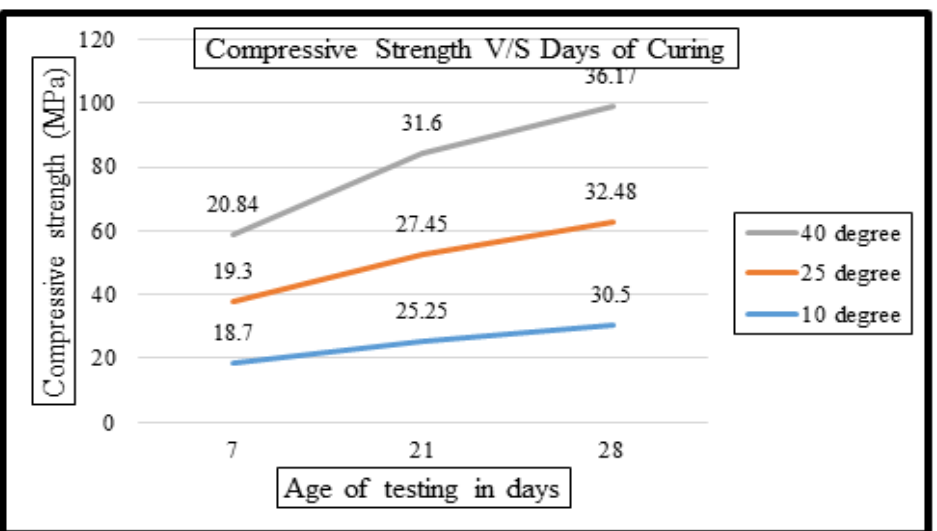

Fig-5: Compressive strength of concrete with age of mixing water temperature 
To examine the impact on water mixing temperature over the compressive strength properties the casted specimens where demolded at different age of concrete 7, 14 and 28 days in accordance to ASTM C39. Based on the observation of results shown in figure 5 , there is increase in early strength of concrete as mix water temperature increased; this may be due to the increase in hydration of concrete at early age concrete. From figure 6 it is clear that there is an $11 \%$ enhancement of compressive strength at 28 days for $40^{\circ}$ $\mathrm{C}$ mix water temperature, by which we can confirm we can reduce the usage of cement for achieving the same strength of concrete at nominal temperature $25^{0} \mathrm{C}$. it is also observed slight negative impact on cold water temperature $10^{\circ} \mathrm{C}$.

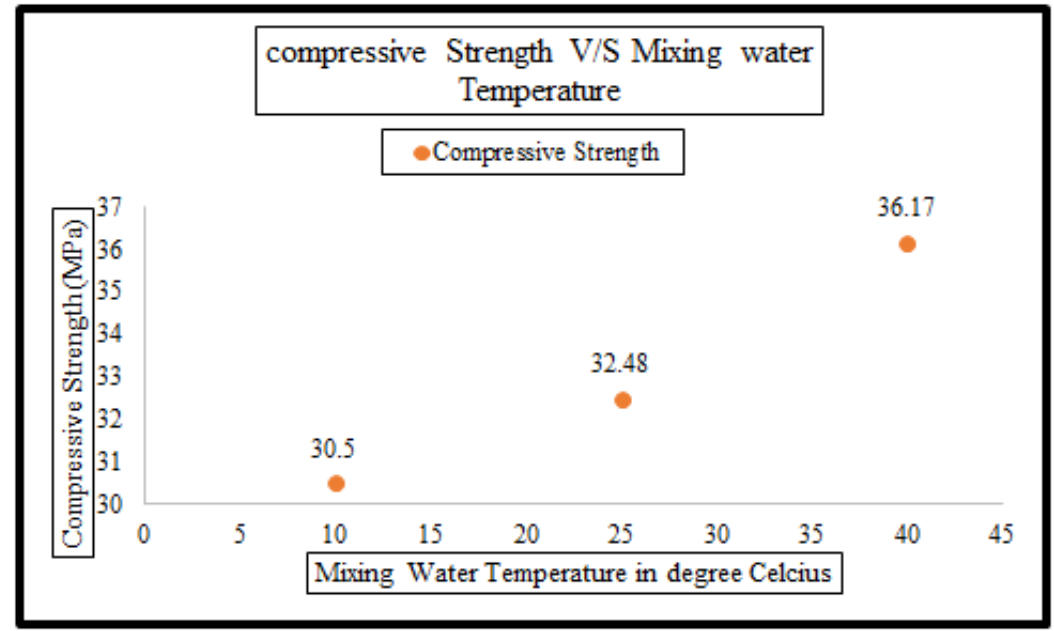

Fig-6: Compressive strength of concrete V/s mixing water temperature at 28 days

\section{Concrete Flexural Strength}

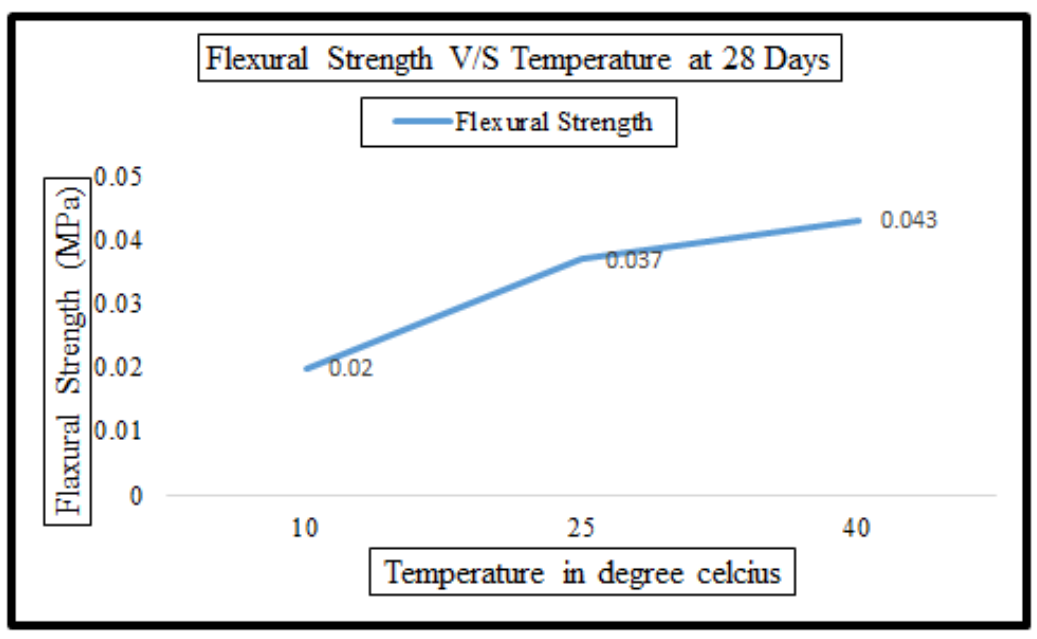

Fig-7: Flexural strength V/s mixing water temperature at 28 days

To study the flexural strength of concrete beams were casted to study of all three mix water temperature concrete where casted at controlled as per ASTM standard and tested at 28 days. Figure 7 explains about the flexural strength of beams for different mix temperature, it was observed that flexural strength of $0.043 \mathrm{MPa}$ for $40^{\circ} \mathrm{C}$ mix water temperature. This reflects with the increase in water temperature when compared to $10^{\circ}$ and $25^{\circ}$. These observed results are reliable to the 28 days compressive strength $10^{\circ} \mathrm{C}$, $25^{\circ} \mathrm{C}$ and $40^{\circ} \mathrm{C}$ mix water temperature.

\section{CONCLUSION}

From the experimental results obtained and data obtained from the background study the following conclusions are drawn.

1. From the literature review, it is not specified in regards to the maximum permissible / allowable water mixing temperature can be used for the production of concrete at high early strength of concrete.

2. From the fresh concrete properties it was observed the slump value will be effected with mix water temperature even though water / binder ratio is kept constant. 
3. Increase in workability and slump with lower water temperature and vice versa for higher temperature up to $40^{\circ} \mathrm{C}$

4. Enhancement of compressive and flexural strength of concrete was found to be at $40^{\circ} \mathrm{C}$ at 28 days by $11 \%$ and $20 \%$ respectively.

Increase in workability and slump with lower water temperature added at $10^{\circ} \mathrm{C}$

\section{ACKNOWLEDGEMENT}

Authors would like to acknowledge Adama Science and Technology University and Research Affairs office for supporting the research activities in the Department.

\section{REFERENCES}

1. Chithra, S., \& Dhinakaran, G. (2014). Effect of hot water curing and hot air oven curing on admixed concrete. International Journal of ChemTech Research, 6(2), 1516-1523.

2. Powers, T. C. (1962). Prevention of frost damage to green concrete (No. 148).

3. Kosmatka, S. H., Kerkhoff, B., \& Panarese, W. C. (2002).Design and control of concrete mixtures (Vol. 5420, pp. 60077-1083). Skokie, IL: Portland cement Association.

4. Naganathan, S., \& Mustapha, K. N. (2015). Effect of water temperature on concrete properties. Jordan Journal of Civil Engineering, 9(3).

5. Nmai, C. K. (1998). Cold weather concreting admixtures. Cement and Concrete Composites, 20(2-3), 121-128.

6. Hasanain, G. S., Khallaf, T. A., \& Mahmood, K. (1989). Water evaporation from freshly placed concrete surfaces in hot weather. Cement and Concrete Research, 19(3), 465-475.

7. Klieger, P. (1958, June). Effect of mixing and curing temperature on concrete strength. In Journal Proceedings (Vol. 54, No. 6, pp. 1063-1081).

8. Roberts, L., Harris, T. (2013). How to Read a Cement Mill Certificate, National Concrete Association NPCA, U.S.A., <https://precast.org/>.

9. Burg, R.G. (1996). The Influence of Casting and Curing Temperature on the Properties of Fresh and Hardened Concrete. Research and Development Bulletin RD113T, Portland cement Association, U.S.A. 